\title{
The Institution of Self-employment as a Factor of Small Business Development in Russia
}

\author{
Irina Molodan ${ }^{1,}{ }^{*}$ Ludmila Ivanchenko ${ }^{1}$ \\ ${ }^{1}$ Reshetnev Siberian State University of Science and Technology, Krasnoyarsk, Russia \\ *Email: ivm444@mail.ru
}

\begin{abstract}
In the context of the spread of self-employment as an alternative to employment, the state faces the task of institutionalising self-employed activities. The creation of norms and rules that ensure its legalisation allows employees to use all the advantages of official employment, including small businesses, and to the state allows for the replenishment of the budget's revenue side. This is why an experiment is being conducted - the introduction of a special tax regime, "Professional Income Tax" (PIT), minimises the self-employed's tax expenses and allows them to receive additional support from the state in case of their official registration. The analysis of the dynamics of the number of registered selfemployed applying the PIT and the receipts of payments for this tax over three years allows us to conclude about the positive results of the experiment. This is the basis for the formation of the institution of the self-employed as a fullfledged subject of SMEs. Along with this, there are unresolved controversial issues on the implementation of the experiment that require additional consideration.
\end{abstract}

Keywords: Labour market, Self-employed, Government regulation of self-employment, Individual entrepreneurship, Professional income tax, Legalisation.

\section{INTRODUCTION}

Scientific interest in self-employment is caused by several reasons reflecting the current state of the labour market. Among them is a change in the economy's structure under the influence of the forces of scientific and technological progress, and, as a result, a change in the structure of the workforce and the emergence of new forms of employment, more adapted to modern reality. The catalyst for the emerging transformation was the COVID-19 pandemic, accompanied by the spread of remote work using Internet technologies. Informal employment is becoming increasingly important both for the Russian economy and for foreign countries, within which the segment of self-employed people who choose to work for themselves is traditionally considered [1, 2, 3]. The task of the state is to ensure the institutionalisation of the activities of the self-employed, to prevent the spread of shadow employment, but on the contrary, to ensure the involvement of the self-employed in legal activities, while with minimal bureaucratic burden, which will enable self-employed entities to receive officially confirmed income, use support tools designed for small and medium-sized enterprises (hence - SMEs), and receive social guarantees, including pension provision $[4,5,6]$. At the same time, the problem of the "stowaway" is being solved; the state budget will receive taxes on the income of the self-employed. The subject of this study is the institute of self-employment, as a set of norms and rules that form the status of official (on a formal basis) self-employment. The study aims to substantiate the possibilities and prospects of official self-employment in the development of SMEs.

\section{RESEARCH METHODOLOGY}

The emergence and rapid increase in the number of self-employed are associated with the onset of a new post-industrial era. The emergence of new non-standard forms of employment is a forced need for a person to adapt to the changing conditions of the labour market, and one of the forms of employment that allows a person to realise his creative potential is self-employment. The purpose of introducing the self-employed category is to 
legalise many persons who produce and sell goods, provide services privately, but do not register their activities anywhere and do not pay taxes.

The legal status of the self-employed in the Russian Federation was approved in 2016 in the Tax Code of the Russian Federation, namely in clause 7.3 of Article 83, "individuals who are not individual entrepreneurs and provide services without hiring employees to individuals for personal, household and other similar needs are considered self-employed" [7]. The status of selfemployed citizens was necessary to improve business conditions in Russia.

The first attempt to legalise self-employed citizens was the patent system proposed in 2013. It was assumed that the self-employed would pay a single fixed payment in the amount not exceeding 20 thousand rubles, regardless of the type of professional activity. Insurance premiums were supposed to be included in the cost of the patent, but this attempt was not fully implemented.

An essential step in the legalisation of self-employed was the adoption in 2017 of Federal law No. 199, which such citizens allocated in an independent group of business entities: "in respect of certain types of business law may provide the conditions for the exercise by citizens of such activities without state registration as an individual entrepreneur." [8] and the introduction of tax holidays with a condition of registration in tax authorities. Since 2017, the self-employed have been granted the right not to pay taxes and insurance fees in the first two years after registration. After the tax holidays ended, it was proposed to stop working or register as an individual entrepreneur and deduct taxes in full. It is important to note that "tax holidays were provided only for three categories of citizens, namely, tutors, housekeepers, nurses, who make up less than $3 \%$ of the total self-employment [9].

The first attempts to legalise the self-employed did not achieve the desired results. During the first three months of the rule on two-year tax holidays, 40 notifications were submitted to obtain the status of selfemployed [10].

According to the Federal Tax Service, as of January 1,2019 , the number of self-employed did not exceed 2121 people. During 2017-2018, 339 out of 3062 registered self-employed people stopped their activities. The reasons for this were a very limited list of activities for the self-employed and an increase in the administrative burden after registration [11].

To maximise the legalisation of the self-employed, Federal Law No. 422-FZ of 27.11.2018 "On experimenting with establishing a special tax regime "Professional Income Tax" (PIT) in the federal city of Moscow, the Moscow and Kaluga Regions, as well as in the Republic of Tatarstan" was adopted. Digital technologies have become the primary tool for the legalisation of the self-employed. The features of the special tax regime are a simplified registration procedure using a mobile application, without visiting the tax authority; exemption from the use of cash registers; automatic creation of receipts for services, full automation of the calculation of the tax amount, control over the limitation on the amount of income, the use of tax deduction; comfortable tax rates.

On December 15, 2019, the President of the Russian Federation signed a law on expanding the tax experiment for self-employed citizens. Since January 1, 2020, the tax experiment has extended to 19 more regions of Russia.

In addition, Federal Law No. 169-FZ of 08.06.2020 amended the Law No. 209-FZ of 24.07.2007 and equated self-employed citizens with SMEs, which will allow them to receive additional support.

Since July 1, 2020, this special tax regime has been in effect throughout the country. The new regime for the self-employed assumes the payment of taxes from the sale of goods, works and services for individuals at a rate of $4 \%$, for individual entrepreneurs and legal entities $6 \%$.

According to statistics, as of March 6, 2019, 38 thousand people have registered in the self-employed status since the beginning of 2019 to take advantage of the special tax regime "Professional Income Tax". The newspaper "Top Secret" in December 2019 reported that the number of self-employed in Russia is 260 thousand people.

According to the Federal Tax Service, by the autumn of 2021, the number of registered self-employed in Russia had reached 3 million people. Thus, the number of self-employed increased more than 11 times during the period under review. Among the reasons for the high growth rates are the following:

- advantages of the tax regime for self-employed people;

- response to the support of the self-employed in the context of the pandemic and the general decline in income of the population: the return to the self-employed of the PIT paid in 2019 in full and the allocation of capital in the amount of 1 minimum wage for the payment of taxes in 2020;

- the development of an online payment system, and, as a result, the complication of tax concealment;

- opportunities for many companies to minimise labour costs by removing employees from the staff and replacing them with external self-employed.

\section{RESEARCH RESULTS}

Following Federal Law No. 422 [12], the experiment has lasted for almost three years. It is possible to analyse 
intermediate results and identify problems and directions of state policy adjustment in relation to self-employment subjects. This period is associated with a crisis in the economy caused by the COVID19 pandemic, which affected the course of the experiment. The decline in demand for many types of products led to a contraction of production in many industries, and representatives of small businesses found themselves in the most challenging situation. At the same time, there was a surge of interest in the official status of the self-employed, which was caused by substantial state support for this category of entrepreneurs. Self-employed persons were fully refunded the PIT in 2020, and a 12,130 ruble subsidy was provided to pay the PIT in 2020 and repay the debt on the specified tax, if any.

With 2020 in the Unified register of subjects of small and average business of the FTS in the statistics of the national project "Small and average business and support of individual entrepreneurial initiative" provides information on the number of self-employed citizens, recorded their status and applying a special tax regime PIT [13], which allowed comparing the population dynamics of the most similar characteristics of the group of enterprises - registered self-employed, applying the PIT (natural persons and individual entrepreneurs (IE) and IE which is SMEs. The period for comparison September 2020 - September 2021 was chosen due to the availability of data in the registry that allows comparison by matching months (Fig. 1). A pattern was revealed during the period under review; the number of sole proprietors of SMEs remained virtually unchanged, while the number of registered self-employed who switched to the PIT increased more than 3 times. The latest statistics at the time of writing the article show that

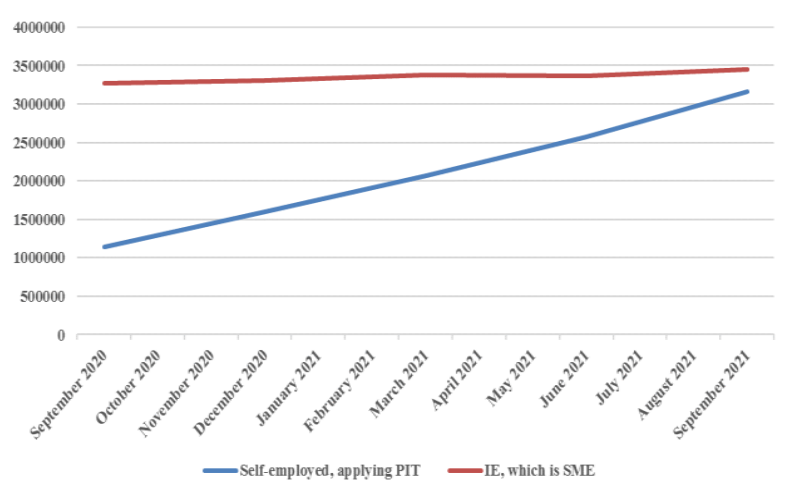

the number of registered self-employed is almost equal to the number of IE, which is SMEs.

Figure 1 Dynamics of the number of registered selfemployed, applying PIT and IE, which is SMEs.

Because the PIT enters the budget of the subjects of the Russian Federation, the change in the number of selfemployed applying the PIT in the context of the regions of the Russian Federation is analysed (Table 1). According to the share of self-employed, the Central and Volga Federal Districts are in the lead, which is explained not only by the presence of the largest megacities but also by the fact that the experiment in these territories began earlier. According to the growth rate of the self-employed (by more than 9 times), the North Caucasus Federal

Table 1. Dynamics of the number of self-employed applying the PIT by the subjects of the Federation of the Russian Federation

\begin{tabular}{|c|c|c|c|c|c|}
\hline \multirow{2}{*}{$\begin{array}{c}\text { Name of the subject of the } \\
\text { Russian Federation }\end{array}$} & \multicolumn{2}{|c|}{ on 30.09 .2020} & \multicolumn{2}{|c|}{ on 30.09 .2021} & \multirow{2}{*}{$\begin{array}{l}\text { growth } \\
\text { rate, \% }\end{array}$} \\
\hline & total, person & share, \% & total, person & share, \% & \\
\hline Russian Federation & $1,143,009$ & 100 & $3,168,286$ & 100 & 277.19 \\
\hline Central Federal District & 591,262 & 51.73 & $1,273,348$ & 40.19 & 215.36 \\
\hline $\begin{array}{l}\text { North-Western Federal } \\
\text { District }\end{array}$ & 104,376 & 9.13 & 350,997 & 11.08 & 336.28 \\
\hline Southern Federal District & 75,137 & 6.57 & 306,790 & 9.68 & 408.31 \\
\hline $\begin{array}{l}\text { North Caucasus Federal } \\
\text { District }\end{array}$ & 9,941 & 0.87 & 91,606 & 2.89 & 921.5 \\
\hline Volga Federal District & 198,567 & 17.37 & 546,113 & 17.24 & 275.03 \\
\hline Ural Federal District & 76,785 & 6.72 & 233,466 & 7.37 & 304.05 \\
\hline Siberian Federal District & 70,726 & 6.19 & 270,129 & 8.53 & 381.94 \\
\hline Far Eastern Federal District & 16,212 & 1.42 & 95,837 & 3.02 & 591.15 \\
\hline
\end{tabular}


Table 2. Analysis of accruals and payments of PIT, thousand rubles

\begin{tabular}{|l|c|c|c|}
\hline \multicolumn{1}{|c|}{ Amounts } & on 01.11.2020 & on 01.11.2021 & growth rate, \% \\
\hline Accrual for payment & $2,467,837$ & $17,920,009$ & 726.14 \\
\hline Received payments, including income: & $2,440,536$ & $16,155,483$ & 661.96 \\
\hline $\begin{array}{l}\text { the consolidated budget of the subjects of the } \\
\text { Russian Federation }\end{array}$ & $1,537,542$ & $10,177,956$ & 661.96 \\
\hline from the consolidated budget to local budgets & 4,245 & 0 & - \\
\hline $\begin{array}{l}\text { Budget revenues of the Federal Compulsory } \\
\text { Medical Insurance Fund }\end{array}$ & $5,977,527$ & $5,977,527$ & 661.96 \\
\hline
\end{tabular}

District stands out as the most depressed region with the highest unemployment rate in the subjects of the Russian Federation (14.8\%).

With the increase in the number of registered selfemployed applying the PIT, both the accruals for the payment of the PIT and the receipt of tax payments have increased, which is reflected in Table 2 [14]. Thus, during the period under review, payments increased almost 7 times.

\section{CONCLUSIONS}

The institute of self-employment can become a factor in the expansion and development of small businesses in Russia. The state, initiating an experiment to establish a special tax regime of the PIT, sought to legalise the selfemployed people's activities, making them full-fledged subjects of SMEs. The data analysis for the past 3 years of the experiment shows good results and allows us to make an optimistic forecast. However, several issues related to the implementation of the experiment remain controversial and require additional consideration. This is due to the specification of the permitted activities of the self-employed who apply the PIT, an increase in the maximum annual income for some categories of the selfemployed (for example, up to 5 million rubles for IT specialists) and the possibility of tax exemption for lowincome self-employed.

\section{REFERENCES}

[1] S. Johansson, I.S. Vinberg, M. Nordenmark, M. Strandh, Subjective well-being among the selfemployed in Europe: macroeconomy, gender and immigrant status // Small Bus Econ 46 (2016) 239253.

[2] F. del Olmo-García, F. Crecenteb, M.Sarabia, Macroeconomic and institutional drivers of early failure among self-employed entrepreneurs: an analysis of the eurozone // Economic Research Economsca Istraživanja 33(1) (2020) 1830-1848.
[3] O.M. Lizina, D.A. Bistyaykina, E. R. Ermakova, T. E. Badokina, T.V. Solovyeva, The informal sector in the structure of the national economy: simulation and evaluation // Journal of Eastern European and Central Asian research 7(3) (2020) 292-304. DOI: http://dx.doi.org/10.15549/jeecar.v7i3.599

[4] A. Plotnikov, Analysis of the relationship between unemployment and self-employment in OECD countries // II International Conference on Economic and Social Trends for Sustainability of Modern Society (ICEST 2021) 116 (2020) 915927.

DOI: https://doi.org/10.15405/epsbs.2021.09.02.103

[5] S. Bakanov, A.A. Aldasheva, M. E. Zelenova, O.V. Runets, Simulation of the self-employed labour supply and demand // International Conference «Humanity in the Era of Uncertainty» (ICHEU 2021) $119 \quad$ (2021) 241-249. DOI: https://doi.org/1015405/epsbs.2021.12.02.30

[6] J. Salonen, L. Koskinen, T. Nummi, The risk of under-insurance in the Finnish statutory pension scheme for self-employed workers: A trajectory analysis // International Social Security Review 73(4) (2020) 25-48. DOI: https://doi.org/10.1111/issr.12249

[7] The Tax Code of the Russian Federation (Part one): adopted by the State Duma on July 16, 1998: approved by the Federation Council on July 17, 1998 [Nalogovyj kodeks Rossijskoj Federacii (chast' pervaya): prinyat Gosudarstvennoj dumoj 16 iyulya 1998 goda: odobren Sovetom Federacii 17 iyulya 1998 goda]. URL: http://www.consultant.ru/

[8] Federal Law No. 199-FZ of 26.07.2017 "On Amendments to Articles 2 and 23 of Part One of the Civil Code of the Russian Federation" [Federal'nyj zakon ot 26.07.2017 N 199-FZ «O vnesenii izmenenij $\quad \mathrm{v}$ stat'i 2 i 23 chasti pervoj 
Grazhdanskogo kodeksa Rossijskoj Federacii»] Retrieved from: http://www.consultant.ru/document/cons_doc_LA $\underline{\mathrm{W} \_220896 /}$

[9] Gidirim, Generation Mobile, or What is happening with the labour market [Pokolenie mobajl, ili CHto proiskhodit $\mathrm{s}$ rynkom truda] Retrieved from: https://raec.ru/live/an.alytics/9862/

[10] D. Nikolaeva, T. Grishina, 40 self-employed people have been identified in Russia [V Rossii vyyavleno 40 samozanyatyh] Retrieved from: https://www.kommersant.ru/doc/3299994

[11] V.S. Skrug, Opportunities and problems of legalising the self-employed in the digital economy [Vozmozhnosti i problemy legalizacii samozanyatyh v usloviyah cifrovoj ekonomiki] // Labour Economics [Ekonomika truda] 7(11) (2020) 979-992.

[12] Federal Law No. 422-FZ of 27.11.2018 (as amended on 02.07.2021) "On experimenting with establishing a special tax regime "Professional Income Tax" (PIT)" [Federal'nyj zakon ot 27.11.2018 N 422-FZ (red. ot 02.07.2021) "O provedenii eksperimenta po ustanovleniyu special'nogo nalogovogo rezhima «Nalog na professional'nyj dohod»]. URL: http://www.consultant.ru/document/cons doc LA W 311977/512cf86a56df0bdea9fb5f14bba79e01a $\underline{90 \mathrm{ed} 7 \mathrm{a} 5 /}$

[13] Statistics for the national project "Small and medium-sized entrepreneurship and support for individual entrepreneurial initiative" [Statistika dlya nacional'nogo proekta «Maloe i srednee predprinimatel'stvo i podderzhka individual'noj predprinimatel'skoj iniciativy»]. URL: https://rmsp.nalog.ru/statistics2.html?t=163930772 $\underline{7717}$

[14] Report on the accrual and receipt of taxes, fees, insurance premiums and other mandatory payments [Otchet o nachislenii i postuplenii nalogov, sborov, strahovyh vznosov inyh obyazatel'nyh platezhej]. URL: Data on forms of statistical tax reporting | Federal Tax Service of Russia / 77 city of Moscow $\underline{\text { (nalog.gov.ru) }}$ 